\title{
Event Marketing and Public Relations ${ }^{1}$
}

\author{
Reba Ellen Hicks, Ricky Telg, and Tracy Irani
}

This publication regarding the stages of a special event is the second of a two-part series on special event planning. The other topic in this series focuses on planning special events and stages of a special event.

\section{Introduction}

Marketing your event so that people know about it and are motivated to attend is extremely important. The five P's of marketing - product, promotion, price, place (location), and public relations - must be taken into consideration in order to have an event that is well attended.

\section{Product}

Your event is the product you want to sell. Whether it is a free event or one for which you are charging admission, your goal is to create an event that will be appealing to your audience.

\section{Place}

The location of your event is very important. In addition to finding a location that is the right size, you also want to find a location for your event that will be relatively easy for your attendees to get to. If it is a publicly held event, will buses or vans be available? How about parking? If it is a private event - for example, a festival held at a school or church parking may be available, but you might need to have team members on hand to help direct people where to park.

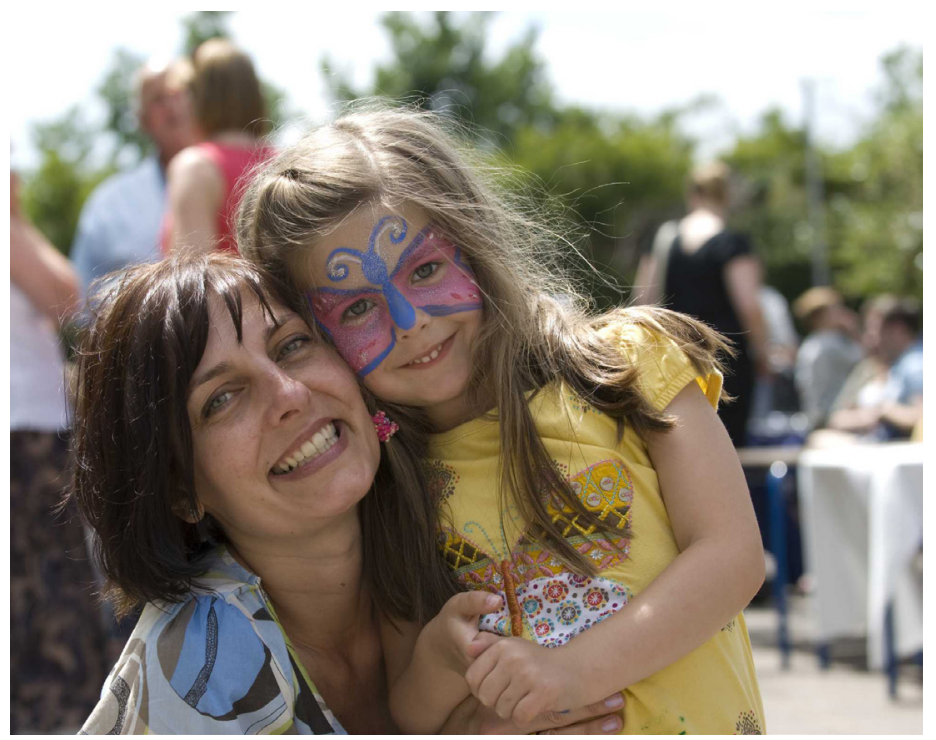

\section{Price}

If you are going to charge for admission to your event, it is important to decide on a price that not only covers your expenses, but that is reasonable and affordable for those you wish to attend. If you have not held this particular event previously, you can ask people beforehand what they would be willing to pay, or you can adjust your price to that of other similar events being held in your area.

\section{Promotion}

Promotion involves all the ways you publicize and make people aware of your event, from word of mouth through advertising and public relations. Putting up a flyer around school to let people know about a special meeting is a form

1. This document is AEC485 (formerly WC148), one of a series of the Agricultural Education and Communication Department, UF/IFAS Extension. Original publication date July 2013. Visit the EDIS website at http://edis.ifas.ufl.edu.

2. Reba Ellen Hicks, graduate student; Ricky Telg, professor; and Tracy Irani, professor, Agricultural Education and Communication Department, UF/IFAS Extension, Gainesville, FL 32611. 
of promotion. Another form of promotion is designing a T-shirt that features your event's special logo and theme. Taking out an ad in the school newspaper, or sending a press release to the newspaper's editor to provide information about the meeting and perhaps get a reporter to come to the meeting and write a story about it - all are ways to use advertising and public relations to promote your event.

\section{Public relations}

Public relations is one of the most effective ways you can use to promote a special event. It has been said that advertising is what you say about an event, while public relations includes what you say, as well as what others say about it. Advertisers pay to run their ads in some form of mass media - newspapers, radio, television, and magazines. With advertising, you control the message you want to communicate in your ad, and also when it runs. This costs money, both for placement and for any production that is done to create the ad. Advertising can be seen to not be credible because ads are basically the claims of the advertiser. If you decide to advertise your event, the costs to create and run your ad are part of the event budget.

Public relations also involves using the news media to promote your event. If a newspaper or a television or radio station decides to cover your event, they will write a news story about it. You have little control over what is said in the story or when it runs, but the resulting publicity is free. In addition, a news story might be seen as more credible and objective than advertising, and it is certainly more affordable.

If you decide to use public relations to promote your event, you may have to dedicate a portion of your budget to create press materials, such as news releases and public service announcements. A news release is a story written by someone in your organization and sent to the media in the hope they will publicize it. For a radio or television station, you could send a news release or, if it is a nonprofit or charitable event, a public service announcement (PSA). PSAs run during the time the station allots for commercials, so they are usually the same length, either 30 or 60 seconds. If the station runs your PSA, the air time is free, as the station is doing a "public service" for the community by letting the public know about your event. In this way, public relations exposure can be more valuable than advertising. For more information about public relations and media relations, please read the EDIS publication series on Media Relations (http://edis.ifas.ufl.edu/topic_media_relations).

\section{References}

Allen, J. (2009). Event planning: The ultimate guide to successful meetings, corporate events, fundraising galas, conferences and conventions, incentives, and other special events ( $2^{\text {nd }}$ ed.). Mississauga, Ontario: John Wiley \& Sons Canada.

Craven, R.E., \& Golabowski, L.J. (2006). The complete idiot's guide to meeting \& event planning ( $2^{\text {nd }}$ ed.). New York, NY: Alpha Books.

Devney, D.C. (2001). Organizing special events and conferences: A practical guide for busy volunteers and staff. Sarasota, FL: Pineapple Press.

Jago, L., Veal, A.J., Allen, J., \& Harris, R. (2000). Events beyond 2000: Setting the agenda. http://utsescholarship. lib.uts.edu.au/dspace/handle/2100/430. Retrieved May 18, 2010. Sydney, Australia: Australian Centre for Event Management. 